\title{
Netherlandish Reports in German Newspapers, 1605-1650
}

\author{
JAN HillgÄRTNER
}

Jan Hillgärtner is lecturer in German at Leiden University. He is completing his $\mathrm{PhD}$ on German newspapers at the University of St Andrews, and has published various articles on this subject. He is also consulting editor of Book History Online (St Andrews).

\begin{abstract}
The shift away from case-studies on individual newspapers towards the study of the geography and space of news is one of the most profound changes in the recent historiography of the newspaper. The new medium that came about at the beginning of the seventeenth century succeeded in parts because it could rely on an efficient international network which transported news. First, this article focusses on the influence as well as the importance of the Netherlandish press for publishers in Germany. It will uncover the exact origin and measure the amount and frequency of Netherlandish news in the German press. This will be done on the basis of a bibliographical analysis of all surviving German periodicals printed between 1605 and 1650 . Netherlandish reports formed part of the backbone of international coverage in German newspapers. Secondly it traces the intellectual and economic influence of Netherlandish publishers. Many of the early publishers failed to establish a business model that would turn their newspaper into a lucrative enterprise. Some of those who managed to keep their periodicals running owned part of their success to the adaptation and appropriation of business models developed in the Northern and Southern Netherlands.
\end{abstract}

Keywords: newspaper, networks, communication, Holy Roman Empire

DOI 10.18352/emlc.62 - URL: http://www.emlc-journal.org

Publisher: Stichting EMLC, supported by Utrecht University Library Open Access Journals | The Netherlands Copyright: The Author(s). This work is licensed under a Creative Commons Attribution-NonCommercial 4.0 International License. 


\section{Netherlandish Reports in German Newspapers, 1605-1650}

\section{JAN HillgärTnER}

Any reader who happened on issue 50 of the Berliner Postzeitung from 1624 could find on the last page of the short periodical a very unusual piece of information:

Here, at Broer Janse's [workshop] one can find the 'Historia Natura/vnd Moral von den West Indien/ worin gehandelt wird/von den mercklichsten dingen deß Himmels Elementen/Metallen/Pflantzen vnnd Thieren.' [...] Described by the Jesuit Joseph de Acosa and translated from Spanish into the Dutch language by Jan Huyghen van Linschoten. ${ }^{1}$

What was the Postzeitung's German reader to make of this? Book advertisements such as this were common in the Dutch press from the 1620 s onwards. They were very rare in German newspapers before the 1640s, however, and when they occurred at all, they usually referred to a book printed or published by the printer of the respective newspaper. That a Berlin newspaper, published by the Brandenburg postmaster Christoph Frischmann in connection with the printer Georg Runge, advertised a Dutch edition was unheard of, and the advertisement was all the more strange because it translated the title of the book into German, while claiming that the book in question had been translated from Spanish into Dutch by Jan Huygen van Linschoten.

The Postzeitung's curious advertisement is a clear indication that the source of Frischmann and Runge's newspaper was Dutch. The German publisher and his editor, the advertisement shows, had mechanically translated what they had found in their Dutch source. Broer Jansz' Amsterdam periodical, the Tijdinghen uyt verscheyde Quartieren. Indeed, the exact same advertisement, albeit in Dutch, can be found in Broer Jansz' coranto of 23 November 1624. Runge did not add the day of publication to his Berliner Postzeitung but given that it appeared at weekly intervals, it is clear that it must have appeared shortly after the Dutch issue. Comparing the Dutch and the German issues reveals that Frischmann or Runge lifted about one third of all reports from the Tijdinghen and translated them for their own

1 'Bey Broer Janse allhie ist in quarto gedruckt, die Historia Natura/vnd Moral von den West Indien/worin gehandelt wird/von den mercklichsten dingen deß Himmels Elementen/Metallen/Pflantzen vnnd Thieren [...] beschrieben durch Josephum de Acosa der Jesuiter Ordens/vor diesem auß der Spanischen/in die Niderländische Sprache vbergesetzt/Durch Jan Huyghen von Linschoten', [Berliner Postzeitung] 50. (Berlin: Georg Runge for Christoph Frischmann, 1624), [6]. 
newspaper. In doing so, they also translated and included this advertisement which in the context of the Berliner Postzeitung made little sense.

Translating and reprinting news was common for the earliest periodicals. This article will uncover the degree of connectedness between the German and Netherlandish press of the seventeenth century. By analysing the entire body of surviving German newspapers, I will show that news from both the Northern and Southern Netherlands made up a considerable part of the reporting throughout the period. Printers and publishers in Germany depended on the constant and reliable stream of news originating from The Hague, Amsterdam, Antwerp and Brussels as well as a wide array of smaller towns across the two regions (the Habsburg Netherlands are but a part of a wider composite/polycentric monarchy). Some publishers maintained a connection with a correspondent or subscribed to a professional news writer; others, who could not afford such an expensive service, made do with translations. Verbatim translations of Netherlandish reports therefore occur regularly in the German press. One publisher even went as far as to translate and reprint an entire periodical on a regular basis. This German reliance on Dutch news sources had far-reaching consequences. By using sources from the Northern and Southern Netherlands, German newspaper publishers could expand the geographical range of their reports, because the Netherlands functioned as the hub of news from overseas to which the Germans would otherwise not have had access.

As the introduction to this issue has argued, newspaper history from its very beginnings has been written mostly from national perspectives. The most severe consequence of this narrow focus was a partial blindness for the international connectedness of news and newspapers in the early modern period. This article places itself firmly in the recent trend towards studying the flow of news rather than their manifestation in one newspaper. It seeks to highlight the importance of the network of news that connected Europe by way of postal exchange. It aims to understand the phenomenon newspaper not solely based on the description and analysis of one or several individual periodicals but by describing the structural mechanisms in terms of news exchange, commercial or ideological connections that were of quintessential importance to the appearance of the newspaper in the early modern period.

\section{Low Countries Newspapers as the Backbone of the German Press}

News from outside the Holy Roman Empire was of great importance to German newspapers in the seventeenth century. Thomas Schröder, in his study of the annual runs of the first two periodicals, has shown that in 1609, 31 percent of all news in the Wolfenbütteler Aviso dealt with matters from outside the Holy Roman Empire. ${ }^{2}$ This proportion was even higher in the Straßburger Relation where 41 percent of all reports came from outside Germany. In both periodicals it was news from the Northern and Southern Netherlands that formed the lion's share of all foreign reports. 
Table 1 The top twenty places of correspondence in German Newspapers (1605-1650).

\begin{tabular}{llll}
\hline Ranking & Instances & Place of Correspondece & Region \\
\hline $\mathbf{1}$ & 7,510 & Cologne & Holy Roman Empire \\
$\mathbf{2}$ & 6,711 & Vienna & Holy Roman Empire \\
$\mathbf{3}$ & 5,516 & Prague & Holy Roman Empire \\
$\mathbf{4}$ & 5,266 & Venice & Italy \\
$\mathbf{5}$ & 4,016 & Rome & Italy \\
$\mathbf{6}$ & 3,291 & Frankfurt & Holy Roman Empire \\
$\mathbf{7}$ & 3,016 & The Hague & Dutch Republic \\
$\mathbf{8}$ & 2,358 & Leipzig & Holy Roman Empire \\
$\mathbf{9}$ & 2,337 & Amsterdam & Dutch Republic \\
$\mathbf{1 0}$ & 2,301 & Nuremberg & Holy Roman Empire \\
$\mathbf{1 1}$ & 2,212 & Paris & France \\
\hline $\mathbf{1 2}$ & 2,047 & Lyon & France \\
\hline $\mathbf{1 3}$ & 1,883 & Antwerp & Southern Netherlands \\
$\mathbf{1 4}$ & 1,848 & Hamburg & Holy Roman Empire \\
$\mathbf{1 5}$ & 1,624 & Regensburg & Holy Roman Empire \\
\hline $\mathbf{1 6}$ & 1,366 & Brussels & Southern Netherlands \\
\hline $\mathbf{1 7}$ & 1,363 & Breslau & Holy Roman Empire \\
\hline $\mathbf{1 8}$ & 1,228 & Franconia & Holy Roman Empire \\
$\mathbf{1 9}$ & 1,039 & Erfurt & Holy Roman Empire \\
$\mathbf{2 0}$ & 1,027 & Augsburg & Holy Roman Empire \\
\hline & & & \\
\hline
\end{tabular}

By studying all surviving newspapers from the period between 1605 and 1650 I have been able to extend Schröder's and Ries' scholarship. ${ }^{3}$ The collection of microfilmed newspapers held at the University of Bremen Library allowed me to examine 12,354 individual newspaper issues. This represents over 97 percent of all surviving issues. In each case, I have recorded the places of correspondence in a database. ${ }^{4}$ All in all, the database contains around 180,000 individual reports from more than 2,000 cities across Europe, Asia, Africa and the Americas. One of the most remarkable findings was that four towns in the Northern and Southern Netherlands appeared amongst the most common places of correspondence (table 1).

While German towns of course dominate this list, the fact that no fewer than four Netherlandish towns appear on it highlights the importance of this region for the German newspapers. Today we can trace a little over 8,600 reports from The Hague, Amsterdam, Antwerp and Brussels and this number accounts for 15 percent of all reports from the twenty most common places of correspondence. With the exception of Italy, which provided a similar number, no other region of early modern Europe provided as many reports as the Northern and Southern Netherlands combined.

4 For a more detailed description of the bibliographic method used see Hillgärtner, 'Die Katalogisierung', 171-185. 
This is not at all what one might expect. France, in theory, was well-qualified to serve as a main purveyor of news: the centralised and heavily influential monarchy maintained relationships across Europe. France's shifting position in European politics and its many domestic and international conflicts were of great interest to many people in Germany and inevitably kindled a demand for French news. Many of the events taking place during the ministry of Richelieu, however, including the Siege of La Rochelle in 1627-28 or his extensive efforts to limit the power of the Spanish Habsburgs, enjoyed relatively little coverage. Indeed, we only find approximately 4,400 reports from Paris and Lyon in the list of the twenty most frequent places of correspondence. This amounted to only half of the output of the Netherlands. Perhaps even more striking is the complete absence of Spanish towns on this list. For a large European power, Habsburg Spain's news network was relatively underdeveloped. Madrid benefitted from a direct postal link with Antwerp. Spain had established a very durable system of written newsletters during the fifteenth and sixteenth century. ${ }^{5}$ As a result, most news from Spain was conveyed to Germany through Antwerp. ${ }^{6}$ With its 163 reports, Madrid was only the $74^{\text {th }}$ most frequent source of news, placing the capital of Habsburg Spain well behind middle-sized towns like Lübeck, Bremen and Basel.

Singling out the twenty most commonly recurring places of correspondence can be regarded as a form of simplification. Moreover, due to uneven issue survival, the numbers presented here are somewhat skewed towards the period of 1630 to 1650 . Nevertheless the study of places of correspondence and the conclusions drawn from it prove to be meaningful. The importance of Dutch reports remains the same even if we extend our focus into the second part of the century. The relatively small but densely populated Northern and Southern Netherlands left an indelible mark on German newspapers. So much so, that any reader would have probably expected at least one report per issue to come from this region.

\section{News from Big Towns and Small Villages}

The distribution of reports sent from the various towns in the northern and southern Netherlands was far from homogenous. One of the most astounding findings of my research is that reporting from the Low Countries was highly centralised. The Hague, Amsterdam, Antwerp, Brussels emerge as the main news hubs, while an array of smaller towns lagged far behind (table 2).

The data reveal that the vast majority of those reports, around 85 percent of the 13,000 reports sent from 138 Netherlandish towns came from The Hague, Amsterdam, Antwerp and Brussels. The 260 reports from Mons, number five on the list, pale into insignificance next to Brussels' 1,336, more than five times as many. The imbalance between news coming from regional and rural locations and those originating from the large cities is striking.

5 Pieper, 'News from the New World', 511.

6 On the news networks between the Habsburg Netherlands and Spain see Arblaster, From Ghent to Aix. 
Table 2 The top twenty places of correspondence of Dutch news in German newspapers (1605-1650).

\begin{tabular}{llll}
\hline Ranking & Instances & Place of Correspondence & Region \\
\hline $\mathbf{1}$ & 3,016 & The Hague & Dutch Republic \\
$\mathbf{2}$ & 2,337 & Amsterdam & Dutch Republic \\
$\mathbf{3}$ & 1,883 & Antwerp & Southern Netherlands \\
$\mathbf{4}$ & 1,336 & Brussels & Southern Netherlands \\
$\mathbf{5}$ & 260 & Mons & Southern Netherlands \\
$\mathbf{6}$ & 252 & Bergen op Zoom & Dutch Republic \\
$\mathbf{8}$ & 143 & Liège & Southern Netherlands \\
$\mathbf{9}$ & 142 & Maastricht & Dutch Republic \\
$\mathbf{1 0}$ & 129 & Arnhem & Dutch Republic \\
$\mathbf{1 1}$ & 105 & Brabant & Dutch Republic \\
$\mathbf{1 2}$ & 63 & Vlissingen & Dutch Republic \\
$\mathbf{1 3}$ & 54 & Valenciennes & Southern Netherlands \\
\hline $\mathbf{1 4}$ & 52 & Breda & Dutch Republic \\
$\mathbf{1 5}$ & 50 & Rotterdam & Dutch Republic \\
$\mathbf{1 6}$ & 32 & Ghent & Southern Netherlands \\
$\mathbf{1 7}$ & 30 & Nijmegen & Dutch Republic \\
\hline $\mathbf{1 8}$ & 30 & Flanders & Southern Netherlands \\
$\mathbf{1 9}$ & 30 & Roosendaal & Dutch Republic \\
\hline & 29 & Utrecht & Dutch Republic \\
\hline $\mathbf{2 0}$ & Ypres & Southern Netherlands \\
\hline
\end{tabular}

The reasons for this stark division lay in the mechanisms of the news exchange in early modern Europe. The four dominant towns that topped the list were the only regular and constant providers of reports. Most of the other towns become important for a limited time only. They peaked once in the stream of news when they became sites of battles or encampments. Schenkenschans is a good example. Officials quickly understood the importance of the town that bordered Germany and controlled river access into the Netherlands. It was fortified following the Act of Abjuration (the juridical acts by which the States-General forfeited the overlordship of Philip II in 1581) and besieged for the first time in 1599. A second siege took place between 1635 and 1636 . And it is exactly during this time that 23 of the 26 reports from Schenkenschans appeared in the German press.

The data reveal significant differences even within the amount of coverage of the four most prominent cities. News from The Hague dominated. With over 3,000 reports, the news-writers of The Hague produced more than double the amount of reports of their counterparts in Antwerp. The Hague had become the seat of the government of the Dutch Republic in 1588. Similar to Vienna and Prague in Germany, the town would henceforth produce a large and constant stream of news that would eventually find its way into the newspapers.

Antwerp's position can be explained due to its strong links with the Spanish Habsburg and entrepôt for the majority of overseas news. The city in the Northern part of the Spanish Netherlands had gained importance as a centre of commerce from around the beginning 
of the sixteenth century. The town furthermore became one of the leading centres in the system of early modern news exchange. The Fuggerzeitungen, if anything, are testament to the connectedness of Antwerp in the sixteenth and seventeenth century. Established as a service with the goal to circulate information amongst the members of the Fugger trading dynasty in the second half of the sixteenth century, these written newsletters circulated between 1568 and 1605. And virtually every weekly newsletter contained at least one report from Antwerp, making the Southern Netherlandish town the most common place of correspondence in the Fugger letters. ${ }^{8}$

Early modern German newspapers contained far more reports originating from the Dutch Republic than from the Southern Netherlands. The table suggest that the proportion of Dutch versus Southern Netherlandish reports was somewhere in the region of 60:40. When we take into account the entire list of 138 places of correspondence in both regions (including the minor or temporary news centres) the numbers become even more skewed: all in all, about 70 percent of reports were dispatched from the Dutch Republic.

\section{Dutch Corantos as a Gateway for Foreign Reporting}

To understand the role of the Northern and Southern Netherlands in Germany's newspaper industry we need to look into the news that was sent from this region. The place of correspondence did not necessarily coincide with the place the news was about. In fact, many news hubs reported on events that had occurred far away. Venice is a prominent example. The Italian city served as the gateway for news from Constantinople and the Ottoman Empire. Often, news from this region travelled by word of mouth or clandestine letters and found their way into the news system only in the Italian port city. ${ }^{9}$

The news hubs of the Low Countries fulfilled a role that was similar to Venice. They were the most important sources of news from the Atlantic and the East Indies, for instance. While such reports had little repercussions on the everyday life of most German readers, they had an exotic appeal that stemmed from the possibility to glance upon the latest occurrences in faraway places. ${ }^{10}$ For a long time, Antwerp and Amsterdam as well as other coastal towns in the Low Countries also relayed the news from Britain to Germany. Having a direct link by postal boat to the British Isles was of course of crucial importance for the transmission of British news (fig. 1).

In his bibliography of the Dutch and Flemish press, Arthur der Weduwen has traced 22,000 reports from 114 places in England, Scotland and Ireland from the period between

7 For a description of the mode written news exchange between the New World and Antwerp see Pieper, Die Vermittlung, 35-49.

8 Barbarics-Hermanik and Pieper, 'Handwritten Newsletters as Means of Communication', 74-75; and Bauer, Zeitungen, 63 .

9 For a more detailed introduction to this see Dooley, 'International News', 158-177.

10 On the coverage of news from the New World see Van Groesen, Amsterdam's Atlantic, 44-57. 

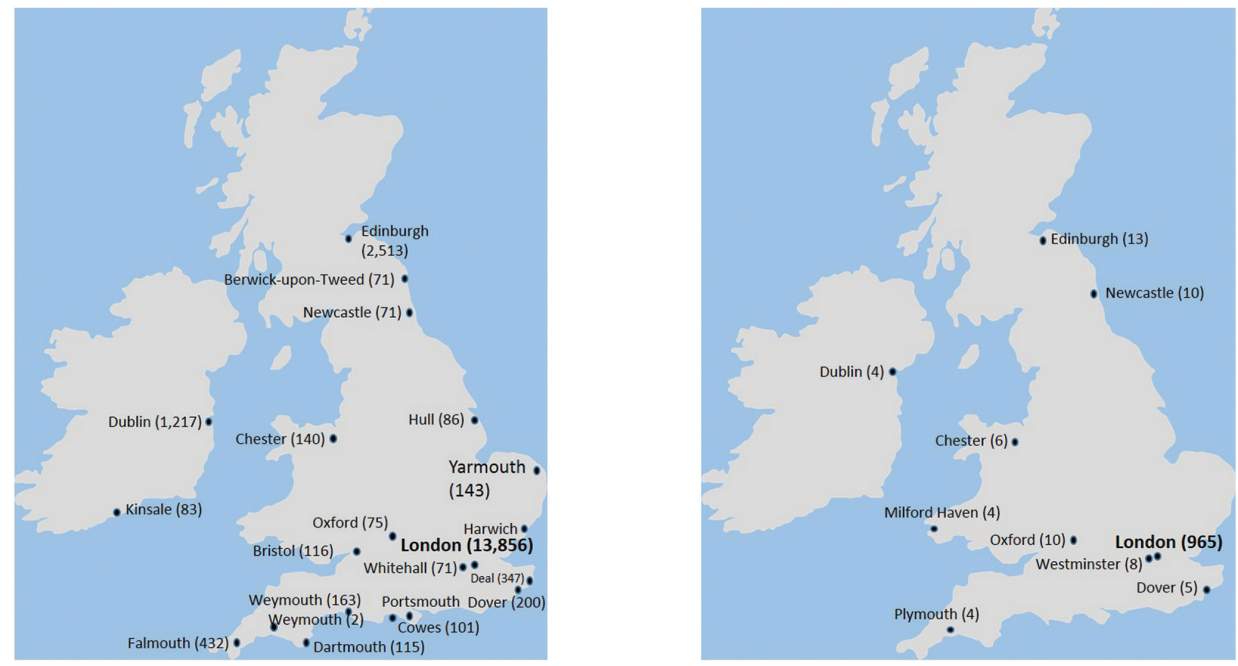

Fig. 1 British news in Dutch and Flemish (left) and German newspapers (right).

1618 and 1700 which appear at least three times in Dutch newspapers. ${ }^{11}$ With over 13,000 reports coming from London, the capital city alone accounted for more than half of all reports. Edinburgh and Dublin with their around 2,500 and 1,200 reports were the only large and regular places of correspondence situated outside England.

The coverage of British matters looked very different in the German press. With around 1,600 reports we find only a fraction of what the Dutch and Flemish newspapers had to offer. A meagre 965 reports came directly from London; a number that was not even remotely close to that in the Netherlandish press. For the period between 1609 and 1650 we can trace thirteen reports from Edinburgh and only four from Dublin. As the second most important place of correspondence, Edinburgh provided nowhere near the 2,500 reports that Dutch readers could find in their papers.

This large difference needs to be interpreted with extreme care, because the figures presented here only partially overlap. The Netherlandish data capture all reports from the period between 1618 and 1700 . At this point we only have the data from German periodicals printed up until 1650 . In both sets of data, the numbers are further skewed towards the latter years as the survival of newspapers improved. Despite these provisos, it is clear that German newspapers contained far fewer reports dispatched from Britain than their Netherlandish counterparts. Furthermore, these reports were sent from fewer places of correspondence.

England, Scotland and Ireland experienced a series of tumultuous and conflicts that would naturally attract the attention of news-writers. The Civil War brought the monarchy to a temporary end and paved the way for constitutional change. Ireland was subject to English colonisation that brought with it waves of immigrants who would kindle the fire 
of confessional conflicts. Charles' attempt to introduce a new Prayer Book into the church in Scotland was met with staunch resistance. The repercussion of this was that the Covenanters resorted to rioting and rebelling, thus dividing the two kingdoms even further than James had brought together. These events caused a wave of largely English royalists to migrate to the Netherlands. Yet these matters were of interest to any reader of the earliest periodicals, regardless of origin or political affiliation.

Comparing the data it might seem as if the British coverage in the Dutch and Flemish newspapers was far more comprehensive, comprising more reports and greater regional diversity. Most of these reports stemming from the British Isles however found their way into the German periodicals not under their British dateline. Amsterdam and The Hague with their direct ferry links to the south coast of England became the gateway for English news. These reports typically appeared in the Netherlandish press under their British dateline. The German publishers who received a great deal of British news from the Dutch press made the editorial decision to incorporate these news items in their Dutch and Flemish reports. The reports were thus were compartmentalised, grouped, and more often re-grouped so that news from London or elsewhere in the British Isles frequently appeared in reports sent from The Hague or Amsterdam. Due to this pattern, if we seek to find British news in the early German press, we need to study the Dutch reports in order to find it. This practice remained relatively stable and in many cases lasted well into the eighteenth century.

\section{Translations and Adaptations}

For Germany's newspaper printers the emergence of the periodical press in the Netherlands was a great stimulus to their business. Many of the earliest newspaper printers drew on the same sources. They either subscribed to the same newsletter services or indeed re-used reports that they had found in other periodicals. Scholars have compared the content of the first newspapers printed in Germany and have found an astonishing degree of overlap. ${ }^{12}$ Stories that appeared in the Straßburger Relation, for example, could also be found in the Wolfenbütteler Relation. Written exchange in the form of commercial newsletters had been the only means of receiving original information from the Dutch Republic and the Southern Netherlands prior to 1618 when Caspar van Hilten started the first newspaper in Amsterdam. With the advent of Dutch and Flemish newspapers, printers in Germany suddenly found another way of running a newspaper business: translating news from Dutch issues and in one case even translating an entire Dutch newspaper to sell in Germany.

Johann Mertzenich was the publisher who engaged most with the Dutch press. In 1620, when he already had thirty years of experience in the publishing business, Mertzenich began publishing his first newspaper in Cologne, the Raporten, which became quite successful. After changing its name to the Wochentliche Postzeitung, in 1625, Mertzenich, a 


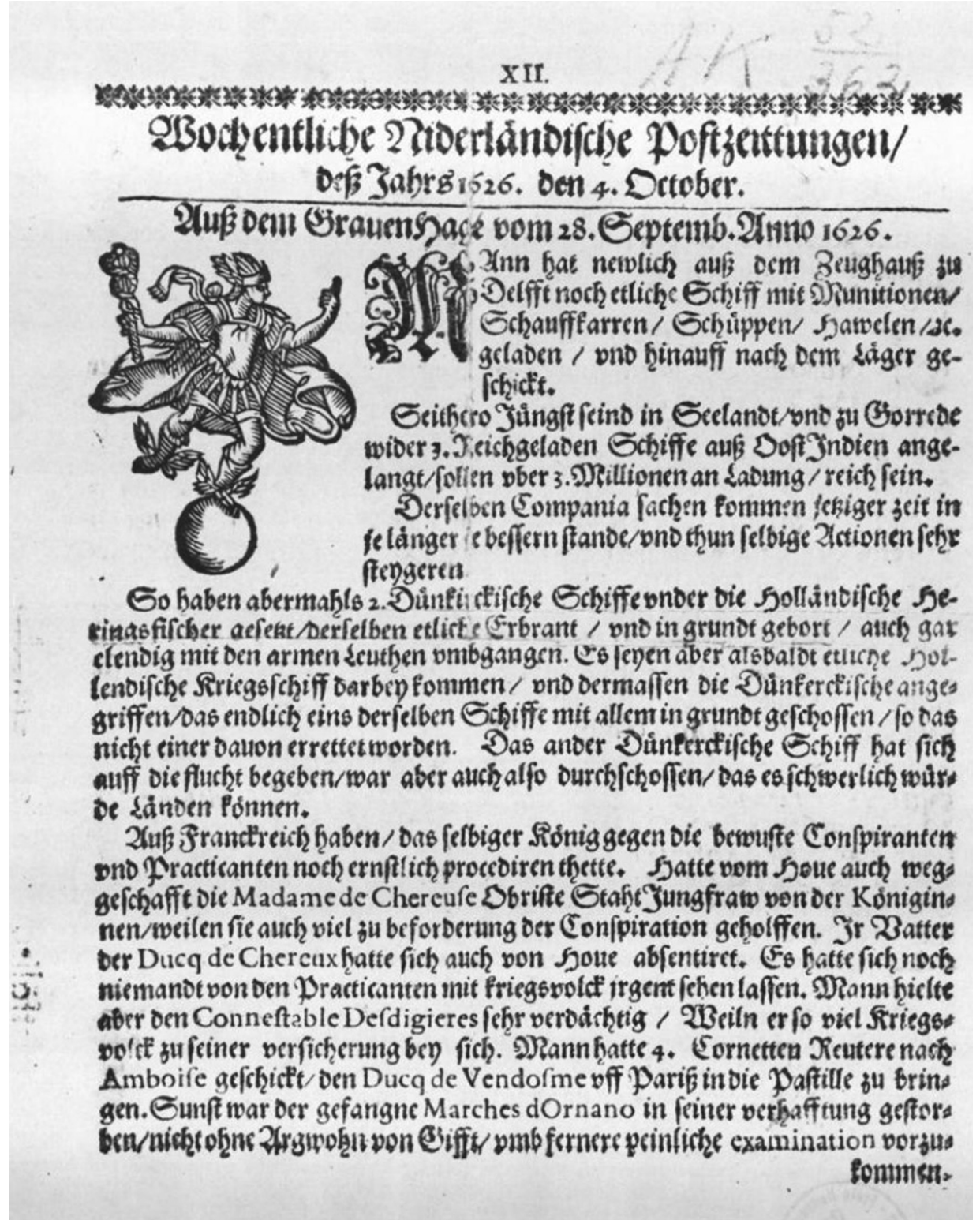

Fig. 2 Johann Mertzenich (ed.), XII. Wochentliche Niderländische Postzeittungen/ deß Jahrs 1626. den 4. October. Cologne 1626, Dresden, Saxon State Archives.

very business-minded printer, sensed that the demand for news allowed for the publication of a second newspaper. In August 1626, he was granted the privilege for this enterprise: the Wochentliche Niderländische Postzeittungen (fig. 2). As in the case of the Raporten, he 
began publishing the newspaper prior to requesting official permission. The earliest known issue of the Dutch newspaper (No. XII), which he probably printed in conjunction with the Wochentliche Postzeitung, is from mid-October 1626. Effectively, he now published a bi-weekly newspaper. This was quite exceptional. Only Lucas Schulte in Oettingen's Continuation der Augspurger (Nürnberger) Zeitung was published in two issues per week. All other German periodicals appeared in weekly intervals in this period.

Mertzenich deliberately chose not to establish connections with providers of manuscript newsletter services. For his Wochentliche Postzeittungen he drew on the Frankfurter Postzeitung as the exclusive source of news. ${ }^{13}$ While Mertzenich chose to obfuscate the link between the Wochentliche Postzeittungen and its German source, he was less secretive about the Dutch origins the Wochentliche Niderländische Postzeittungen, which openly indicated the date of publication of the corresponding Dutch periodical. He did not indicate which newspaper he translated, however. Due to the poor survival rates of both Merzenich's newspaper and the early Amsterdam newspapers, none of the reports in the first issue can be linked to a surviving Dutch newspaper. Comparing the few surviving issues from 1628 to 1630 reveals that Mertzenich used the Courante uyt Italien ende Duytschlandt as his source. ${ }^{14}$

To source his news from existing newspapers was obviously the most cost-effective choice, but also a risky strategy given the biased reporting in papers from other cities. Mertzenich generally followed the Dutch original but omitted reports from the Habsburg Empire on various occasions. The Courante uyt Italien ende Duytschlandt of 11 November 1628 opened with a report from Vienna, stating that the Spanish ambassador had arrived at the court. ${ }^{15}$ This report did not appear in the German translation, perhaps reflecting Mertzenich's desire not to attract the attention of those loyal to Habsburg Austria. Candid reporting almost landed Mertzenich in trouble, however, when the Bishop of Osnabrück complained to the council of Cologne about a report that he had found in Wochentliche Postzeittungen. ${ }^{16}$ In his defence, Mertzenich pointed out that he had only reprinted what he had found in a Frankfurt newspaper. Since the censors in Frankfurt had deemed the report fit for publication, he was not held responsible.

Eventually, however, imperial politics caught up with the Wochentliche Niederländische/vnd andern Orthen Postzeitungen. The end of Mertzenich's venture came in February 1632 when Emperor Ferdinand II ordered the council to ban the newspaper. The council notes reveal that the Emperor objected to the 'incorrect and false' reporting of the newspaper without elaborating which particular report or reports had caused unease. ${ }^{17}$ Prohibiting the publication of a newspaper altogether was a hefty sanction; the normal procedure would have been to caution Mertzenich. A possible explanation for this can be

13 Roeder, Frühe Kölner Wochenzeitungen, 91-92.

14 Mertzenich's periodical does not survive very well in this period. We can however trace a pattern that suggests that Mertzenich translated his news from the Courante uyt Italien. A small number of reports in Mertzenich's newspaper might have been translated from Broer Jansz's Tijdinghen uyt verscheyde Quartieren, a second periodical in circulation during the same period.

15 Courante uyt Italien ende Duytschland, etc. [11 November 1628] (Amsterdam: Caspar van Hilten, 1628), [1].

16 Roeder, Frühe Kölner Wochenzeitungen, 95.

17 'incorrect and false', cited after Roeder, Frühe Kölner Wochenzeitungen, 103. 
found in Cologne's situation at the turn of 1631/1632. The Swedish army led by Gustavus Adolphus had taken control over large parts of northern Germany. Cologne became hemmed in between the Dutch Republic and regions loyal to the Swedes. An invasion of the Rhineland seemed likely in these circumstances. Roeder speculates that the circulation of Dutch newspapers in translation in neutral Cologne could have helped stimulate antiHabsburg sentiments. ${ }^{18}$

A council note from August 1627 revealed that Mertzenich was not the only Cologne publisher to translate a Dutch newspaper. ${ }^{19}$ According to the note, an unnamed printer, residing at 'vnder 16 heuser' was banned from printing a newspaper for the period of six weeks after he contracted the plague. The workshop at this address belonged to Betram von Hilden, official printer to the juridical and theological faculty of the university. ${ }^{20}$ No evidence of Von Hilden's newspaper survives and it is likely that his stint in the newspaper industry was rather short. Scholars disagree over the dates of his life, arguing that he either died in 1627 or 1650 . Assuming that he succumbed to the plague in 1627 would explain why Mertzenich's privilege for a newspaper printed after a Dutch template remained unchallenged. A third attempt at publishing a newspaper from the Low Countries was made by Heinrich Krafft in 1629. This local competitor of Mertzenich applied for a privilege to translate a newspaper from Antwerp and publish it as his weekly periodical in order to serve the pro-Habsburg market Mertzenich did not cater to. While the council granted his wish on 7 September $1629,{ }^{21}$ no evidence of Krafft's periodical has survived. Probably, Krafft's newspaper failed to ever materialize because Abraham Verhoeven, the publisher of the only Antwerp periodical in this period, fell from grace with the authorities exactly when Krafft obtained his privilege. When Verhoeven's Nieuwe Tijdinghen ceased to exist in 1629 , this robbed Krafft of his source. ${ }^{22}$

The Raporten and its immediate successors remained the only newspapers printed in Cologne's for most of the seventeenth century thanks to the support of the council. The council successfully thwarted all attempts at publishing another newspaper with the exception of the Dutch translations that appeared alongside the Wochentliche Niederländische/ vnd andern Orthen Postzeitungen between the late 1620 s and the general ban of translated newspapers in 1632 that resulted from Ferdinand's intervention.

In 1637, another printer, Arnold von Kempen, obtained the privilege to continue publishing Mertzenich's periodical. Born into a Cologne printing dynasty, Arnold von Kempen had started working as a printer in 1609 . One year later he had already become the official printer to the arts faculty and almost immediately also to the faculty of law. ${ }^{23}$ He enjoyed considerable economic success and his appointment as official printer to the council of Cologne certainly must have proved a lucrative deal. His good relations with the council must have helped him to obtain the permission to continue the Mertzenich titles. Like Mertzenich, Von Kempen faithfully translated what he found in the Courante uyt

18 Roeder, Frühe Kölner Wochenzeitungen, 104-105.

19 Roeder, Frühe Kölner Wochenzeitungen, 21-22.

20 Reske, Die Buchdrucker, 466.

21 Roeder, Frühe Kölner Wochenzeitungen, 22-23.

22 Der Weduwen, Dutch and Flemish Newspapers, 326-333.

23 Heitjan, Die Stellung, 1255. 
Italien ende Duytschlandt. But we would underestimate Von Kempen's role in the German book industry if we were to think of him as a mere translator and reprinter of a Dutch newspaper: he also imported Dutch innovations.

One of the things Von Kempen learned from his exposure to the Dutch press was the commercial mechanics of book advertisements. Von Kempen was one of the very few German newspaper printers who started to include book advertisements in his periodical. The few others who did so exclusively advertised editions from their own workshop. Issue XLIX of the Ordinari Wochentliche Dinstags Postzeittungen of 1645 contained a note advertising 'at the Pfaffenpforte in Cologne one can find a description of the history of Cologne, titled Vbiorum historia, Nobilitaes, Sacrarium, Fasti, \&c.'. ${ }^{24}$ Today, we can trace the edition advertised, despite the corrupted title description. It is the lengthy work of one of Cologne's most respected historians of the seventeenth century, Aegidius Gelenius. ${ }^{25}$ The edition was printed by Von Kempen's competitor Jost Kalckhoven. No evidence of a commercial cooperation between Von Kempen and Kalckhoven survives. This makes it highly probable that Von Kempen at least occasionally sold advertisement space in his newspaper to fellow printers from Cologne. ${ }^{26}$

\section{Not by Coincidence but by Design}

The early history of the newspaper was one of trial and error. And error prevailed for many trying to make a living from this presumably lucrative business. Mertzenich, and after him Von Kempen, fared well when he increased the periodicity from one to two issues per week thanks to the translation of an Amsterdam newspaper. For others, however, adapting Netherlandish standards did not yield success.

The design favoured in national newspaper cultures remained distinctively different throughout the entire seventeenth century. Despite the proximity of the Northern and Southern Netherlands to Germany, printers followed their own typographical conventions when it came to the design of their newspapers. In the Holy Roman Empire, printers by and large followed the model set forth by Johann Carolus and Julius Adolph von Söhne. They published newspapers in quarto format; usually four to eight pages in length. News was arranged in a way that resembled the standards for book typography of the seventeenth century. It appeared as a block of text set in a single column, with the indented places of correspondence marking the beginning of each report. Many of those newspapers came with separate title pages. They were often used to capture the attention of

24 'Zu Cölln bey der Pfaffenpforten ist zu finden ein Historische Cölnische Beschreibung auff Latein/intitulirt [...]', Num. XLIX. Ordinari Wochentliche Dinstags Postzeittungen deß Jahrs 1645. vom 5. December. (Cologne: Arnold von Kempen, 1645), [4].

25 Aegidius Gelenius, De Admiranda, Sacra, Et Civili Magnitudine Coloniae Claudiae Agrippinensis Augustae Ubiorum Urbis (Cologne: Jost Kalckhoven, 1645).

26 A second case supports this assumption. Issue $\operatorname{xxxx}$ of the Ordinari Wochentliche Dinstags Postzeittungen from 1650 contained an advertisement for an almanac, published in Cologne by Gerhard Altzenbach. The edition in question has not survived. Once again it is more than likely that Von Kempen received money in exchange for the possibility of advertising in his newspaper. 
potential readers. Publishers elaborated and expanded on the week's news and highlighted the most remarkable stories in short texts. Hyperbolic language and the usage of bold vocabulary was common. Other, more sober publishers would provide a list of the places of correspondence in that issue. Title pages either resonated with the thirst for news and the attraction of violence and the darker side of humanity or worked as a tool to structure the content of an issue, similar to a table of contents. The trend of separate title pages was particularly prominent in the period up to 1635 . It began to fade after that and from the 165 os onwards we rarely find a newspaper with a separate title page. Printers in the Northern and Southern Low Countries opted for a very different model. They chose the large folio format onto which they printed the text in two columns, using a relatively small type to cram as much text as possible into every issue.

The visual differences were stark and the conventions established by the earliest newspaper printers in Germany and the Netherlands remained intact well into the eighteenth century. In consequence this meant that anyone familiar with the medium who came across an issue, could easily tell even from a distance whether they were dealing with a German or Dutch copy. This was certainly not an orchestrated attempt at building a brand image on the part of the publishers. Nevertheless, it worked to that effect.

The conventions for the design of a newspaper allowed for some flexibility and even experiments. Moritz Vogt, who lived close to the border with the Dutch Republic in Herford, opted for the Dutch, rather than the German conventions. Vogt was active in the small Imperial City as a printer between 1625 and $1630 .{ }^{27}$ Coming from Magdeburg, where he published several editions from 1621 onwards, he was the first printer to work from Herford. From 1630 onwards, he started to print an unusual newspaper, the Conivnvnd Avgirte Wöchentliche Avisen.

Vogt did not follow the easiest career path for a newspaper publisher. Many established newspaper publishers were seasoned printers, experienced in providing cheap broadsheets or pamphlets. Crucial to their business model was their capability to judge what was marketable and to print and sell it at a reasonable price. Those who succeeded at this understood how to create a demand rather than to respond to it. Vogt had been a very different kind of publisher, and his move to publish a newspaper was rather unusual. His remaining work shows that before he began his newspaper, he catered for a local audience with jobbing work. Eight editions survive from his stint in Herford, most of which were funeral sermons commissioned by local dignitaries. For a printer, this was a lucrative deal: commissioned editions were paid upfront, which minimised many of the risks that anyone active in the print industry of the seventeenth century regularly had to face. Yet it was quite something else to run a newspaper. A newspaper publisher needed to maintain and finance a network of correspondents or subscribe to a newsletter, When Vogt began publishing Herford's first periodical, the Conivn- vnd Avgirte Wöchentliche Avisen (fig. 3), he probably lacked this experience.

Much of the history of Vogt's periodical remains obscure. The only surviving issue appeared on 18 October 1630 . Due to this shortage of evidence it is impossible to discern 


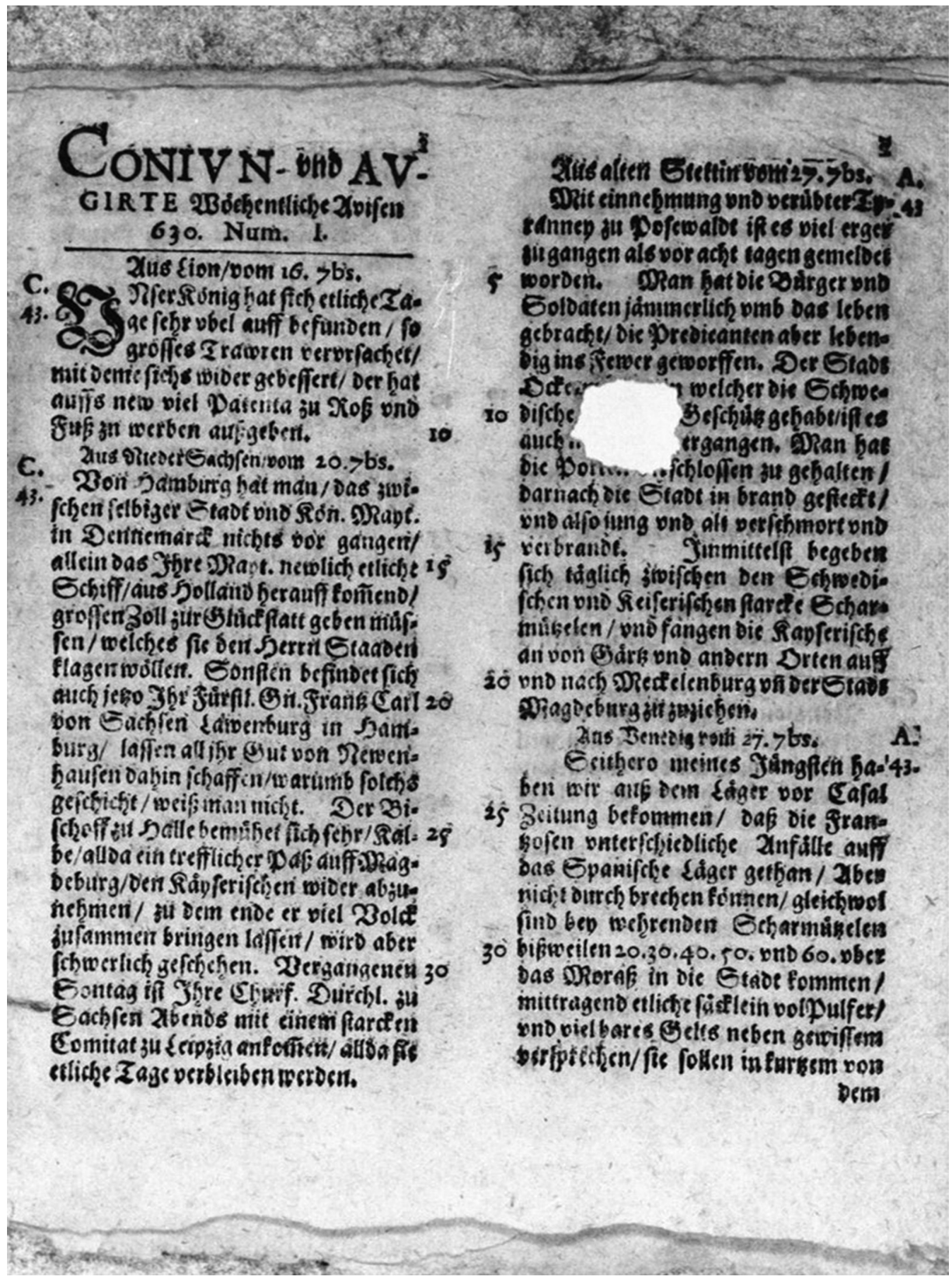

Fig. 3 Moritz Vogt (ed.), Conivn- und AVGIRTE Wöchentliche Avisen 63o. Num. I, Herford 1630, p. [1], Bielefeld, University Library. 
how long the newspaper lasted. However, it is safe to assume that Vogt's periodical did not enjoy a great deal of success and quickly ceased publication.

Herford's proximity to the Dutch Republic may have provided Vogt with stylistic models of Dutch newspapers. In his Conivn- vnd Avgirte Wöchentliche Avisen, Vogt printed the news in two columns on eight pages. This reflected the general visual appearance of Dutch newspapers. Only three newspapers with news printed in two columns can be found in Germany during the seventeenth century, coming into fashion from the 1670 s onwards but remaining a minority. ${ }^{28}$ Vogt furthermore deviated from the standard model of German newspapers by providing a line count next to both columns. ${ }^{29}$

Closer inspection of the copy reveals that Vogt went for a hybrid mix between the Dutch and German style. Whereas the Dutch printers spread their news over two folio pages, Vogt preferred the smaller quarto page with a large type. This was not a very wise choice. Paper was one of the most important cost factors in the production of any edition in the seventeenth century. Any printer who wanted to maintain a viable newspaper business needed to use this commodity in an economic manner. The Dutch typographic model allowed for a cost-efficient production as printers did not shy away from filling their papers to the edge with text. In the mid-1620s, the amount of text on a single page of an Amsterdam newspaper could run up to 2,00o words. ${ }^{30}$ Vogt's Conivn- vnd Avgirte Wöchentliche Avisen, by contrast, required eight pages to print 2,500 words. The choice of a larger type and smaller format meant that Moritz Vogt had to use double the amount of paper per issue compared to his Dutch colleagues.

Most German newspapers of the seventeenth century had a rather generic title, often featuring the terms 'Zeitung', 'Aviso' or 'Relation'. The title of Voigt's weekly 'avisos' further referred to the editorial practices of collecting and distributing news. The two components of the title, 'Conjugieren' and 'Avigieren' (both modernised), can be translated as 'collected' and 'augmented'. Next to each report he indicated with a capital 'A' or ' $\mathrm{C}$ ' whether he had taken the report directly from another newspaper or enriched it with additional information. Vogt's claim to pre-select only true reports and enrich them with additional information was unique in the context of the Early Modern press. An editorial stance like this required him to stay abreast of the latest news and have all critical information confirmed by several sources in order to ensure their veracity.

Vogt did not fulfil his promises. News from this issue dealt with the aftermath of Gustavus Adolphus' entry into the Thirty Years' War during the summer of 1630. The issue reports mainly on events of that conflict occurring between 16 July and 14 August. Gustavus Adolphus' landing on Usedom on 6 July stimulated hopes and fears amongst the Germans. The contents of the Conivn- vnd Avgirte Wöchentliche Avisen provide a good example of the frequently conflicting news items that were typical for the German newspaper in the seventeenth century. The people of Pomerania, according to a report from Breslau (the present Wrocław), feared that even more Imperial troops would be deployed in the country and that general Montecuccoli could devastate the region. Any reliable news

28 Hillgärtner, Die Entstehung, 52-59.

29 Numbering the lines later became a feature of Flemish newspapers from the 1660 onwards.

30 Der Weduwen, Dutch and Flemish Newspapers, 18. 
about the location and intentions of the Swedish king was hard to gather from this issue. A report from Hamburg stated that Gustavus had landed in Dassow, three miles from Lübeck and that he had begun to lay siege upon Rostock with over 30,000 men. A Leipzig report mentioned that news from Stettin had been held up by bad weather. Any reader could feel the unease of the anonymous writer of these lines who complained about conflicting news of Gustavus's progress in Northern Germany. According to hearsay and rumours, the Swedish King had already landed. But the correspondent dutifully noted that other reports claimed that the king was still at sea and could not land due to poor weather conditions.

This specific case of reporting reflects the general trends in broadcasting news in the newspaper of the seventeenth century. The press often contained contradictions and discrepancies. ${ }^{31}$ Publishers were acutely aware of this flaw. Most of them deliberately did nothing to mitigate it, instead following a principle known as relata refero. This meant that they faithfully published everything that they had been provided with by their correspondents or the newsletter services that they had subscribed to. ${ }^{32}$ This was a deliberate and proactive measure against the possibility of persecution. Many authorities, whether local councils, dukes, princes or even the Emperor campaigned against newspapers over claims of false and defamatory reporting. It was generally regarded as a strong argument against such allegations if the publisher could prove that he or she had only repeated a piece of information that came from elsewhere and that it did not originate from their newspaper. Most publishers followed this principle and in turn accepted incongruities in their reporting. Moritz Vogt was no exception. Any reader taking his editorial claims at face value would have expected to find a newspaper free from this burden.

Vogt's move to adapt elements of the Dutch typographical conventions is less surprising if we consider how intimately Herford's fate had been entangled with that of the Dutch Republic. A military conflict over the right of succession of the Duchy of Jülich-Cleves Berg erupted after Duke Johann Wilhelm died childless in 1609. The hinterland of the territory became a popular refuge for those who fled the Dutch regions ravaged by the Eighty Years' War. Herford itself had a troubled history. At some point it was part of the Duchy of Jülich-Cleves-Berg but the status of imperial immediacy remained contested throughout most of the sixteenth and seventeenth centuries. Moreover, Herford was a hanseatic city. Cloth-makers and other tradespeople had managed to establish firm connections with trade partners in the neighbouring Dutch Republic and Southern Netherlands. ${ }^{33}$ Thus the Dutch language and periodicals from Amsterdam and Antwerp probably enjoyed some currency in this city, prompting Vogt to model his newspaper accordingly.

\section{Conclusion}

This study of the close links between the Netherlandish and German press has revealed how strongly newspapers from different countries depended on each other. In order for

31 Weber, 'Der große Krieg', 39-40.

32 Berns, 'Parteylichkeit', 131-133.

33 Blanke, 'Bündnis im Wandel', 104-107. 
German publishers to be able to cover the most important events they had to translate and appropriate news that they had either received from correspondents in the Northern and Southern Netherlands or, as was the case in Mertzenich's newspaper, translate and republish a periodical from across the border.

The history of the early press is a story of the mutual influences and dependencies between publishers in Europe's different regions and countries. New bibliographic tools have made it possible to analyse large sets of data and analyse the entanglement of national press histories. German newspapers show that the reports sent from across the Northern and Southern Netherlands had already early on become an integral component. More than any other state bordering the Holy Roman Empire it was the Northern and Southern Netherlands that provided a considerable proportion of news that were subsequently printed in German periodicals. The close ties with overseas regions ranging from Britain into the Atlantic and Pacific world ensured that Dutch news-writers and publishers received a steady stream of news from these regions that they could incorporate into their reporting.

The case studies showed just how receptive German publishers were to the Netherlandish way to run a newspaper. Advertisements had from an early point in time played an important part in the Amsterdam press. Including paid advertisements for goods and services in their periodicals meant an additional stream of income that lowered the risk of financial failure. It was due to people like Johann Mertzenich and their exposure to Netherlandish periodicals that this business idea would spread into Germany. But this was not immediately applied by everyone in the industry. Most of the advertisements prior to 1650 aimed to sell books published by the respective printer of the newspaper. Advertisements were a convenient way that could occupy any remaining space at the end of the issue. The study of the Wochentliche Niederländische/vnd andern Orthen Postzeitungen reveals an approach that focussed on advertising books from other publishers. It was not before the 1670 s that newspaper advertising in Germany occurred on a similar scale to that of the Northern and Southern Netherlands.

Much of the success in the world of the early newspapers depended on being in the right location and the experience in a competitive market for print. The Netherlandish market was driven very much by competition as many towns were home to more than one newspaper. One of the distinctive features of the Netherlandish press was its economic use of paper, one of the main cost factors in the early modern print world. Moritz Vogt who in essence tried to run a newspaper modelled after a Netherlandish prototype failed because he lacked both the market and the experience to run a newspaper. For him, 'going Dutch' did not yield a great deal of success.

\section{Bibliography}

Arblaster, Paul, From Ghent to Aix. How They Brought the News in the Habsburg Netherlands, 1550-1700 (Leiden 2014).

Barbarics, Zsuzsa and Renate Pieper, 'Handwritten Newsletters as a Means of Communication in Early Modern Europe', in Francisco Bethencourt and Florike Egmond (eds.), Cultural Exchange in Early Modern Europe. Vol. III: Correspondence and Cultural Exchange in Europe, 1400-1700 (Cambridge 2007), 53-79. 
Bauer, Oswald, Zeitungen vor der Zeitung. Die Fuggerzeitungen (1568-1605) und das frühmoderne Nachrichtensystem (Berlin 2011).

Beermann, Matthias, Zeitung zwischen Profit und Politik, der Courier du Bas-Rhin (1767-1810). Eine Fallstudie zur politischen Tagespublizistik im Europa des späten 18. Jahrhunderts (Leipzig 1996).

Berns, Jörg Jochen, 'Parteylichkeit and the Periodical Press', in Kathryn Murphy and Anita Traninger (eds.), The Emergence of Impartiality (Leiden 2014), 87-139.

Blanke, Lore, 'Bündnis im Wandel: Die Hansestadt Herford im 15. Jahrhundert', in Wolfgang Otto (ed.), Zur Geschichte der Stadt vom Mittelalter bis zur Frühen Neuzeit (Leopoldshöhe 1996), 104-111.

Dooley, Brendan, 'International News Flows in the Seventeenth Century: Problems and Prospects', in Joad Raymond and Noah Moxham (eds.), News Networks in Early Modern Europe (Leiden 2016), 158-177.

Fellmann, Dorothea, Das Gymnasium Montanum in Köln 1550-1798. Zur Geschichte der Artes-Fakultät der alten Kölner Universität (Cologne 1999).

Frischmann, Christoph (ed.), [Berliner Postzeitung] No. 50. (Berlin: Georg Runge for Christoph Frischmann, 1624).

Gelenius, Aegidius, De Admiranda, Sacra, Et Civili Magnitudine Coloniae Claudiae Agrippinensis Augustae Ubiorum Urbis (Cologne: Jost Kalckhoven, 1645).

Groesen, Michiel van, Amsterdam's Atlantic. Print Culture and the Making of Dutch Brazil (Philadelphia 2017).

Heitjan, Isabel, 'Die Stellung der Buchgewerbetreibenden in der Stadt Köln und zu ihrer Universität (15. bis 18. Jahrhundert), Archiv für Geschichte des Buchwesens 11 (1971), 1129-1358.

Hillgärtner, Jan, Die Entstehung der periodischen Presse. Organisationen und Gestalt der ersten Zeitungen in Deutschland und den Niederlanden (1605-1620) (Erlangen 2013).

Hillgärtner, Jan, 'Die Katalogisierung der deutschen Presse des 17. Jahrhunderts im Universal Short Title Catalogue (USTC)', Jahrbuch für Kommunikationsgeschichte 16 (2014), 171-185.

Hillgärtner, Jan, German Newspapers 1605-1650. A Bibliography (Leiden, forthcoming).

Hilten, Jan van (ed.), Courante uyt Italien ende Duytschland, etc. [11 November 1628] (Amsterdam: Jan van Hilten, 1628).

Kempen, Arnold von (ed.), Num. XLIX. Ordinari Wochentliche Dinstags Postzeittungen deß Jahrs 1645. vom 5. December. (Cologne: Arnold von Kempen, 1645).

Mertzenich, Johann (ed.), XII. Wochentliche Niderländische Postzeittungen/ deß Jahrs 1626. den 4. October. (Cologne, Johann Mertzenich, 1626).

Pieper, Renate, Die Vermittlung einer neuen Welt. Amerika im Nachrichtennetz des habsburgischen Imperiums 1493-1598 (Mainz 2000).

Pieper, Renate, 'News from the New World: Spain's Monopoly in the European Network of Handwritten Newsletters during the Sixteenth Century', in Joad Raymond and Noah Moxham (eds.), News Networks in Early Modern Europe (Leiden 2016), 495-511.

Raymond, Joad and Noah Moxham, 'News Networks in Early Modern Europe', in Joad Raymond and Noah Moxham (eds.), News Networks in Early Modern Europe (Leiden 2016), 1-16.

Reske, Christoph, Die Buchdrucker des 16. und 17. Jahrhunderts im deutschen Sprachgebiet. Aufder Grundlage des gleichnamigen Werkes von Josef Benzing. 2., überarbeitete und erweiterte Auflage (Wiesbaden 2015).

Ries, Paul, 'Der Inhalt der Wochenzeitungen von 1609 im Computer', in Elger Blühm and Hadwig Gebhardt (eds.) Presse und Geschichte II. Neue Beiträge zur historischen Kommunikationsforschung (Munich 1987), 113-125.

Roeder, Corinna, Frühe Kölner Wochenzeitungen. Die Unternehmen der Offizinen Mertzenich und Kempen. 1620 bis 1685 (Cologne 1998).

Schröder, Thomas, Die ersten Zeitungen. Textgestaltung und Nachrichtenauswahl (Tübingen 1995).

Vogt, Moritz (ed.), Conivn- und Avgirte Wöchentliche Avisen 63o. Num. I. (Herford: Moritz Vogt, 1630).

Weber, Johannes, 'Der große Krieg und die frühe Zeitung. Gestalt und Entwicklung der deutschen Nachrichtenpresse in der ersten Hälfte des 17. Jahrhunderts', Jahrbuch für Kommunikationsgeschichte 1 (1999), 23-61. 
Weber, Johannes, “Unterthenige Supplication Johann Caroli/Buchtruckers”. Der Beginn gedruckter politischer Wochenzeitungen im Jahre 1605', Archiv für Geschichte des Buchwesens 38 (1992), 257-265.

Weduwen, Arthur der, Dutch and Flemish Newspapers of the Seventeenth Century, 1618-1700, 2 vols. (Leiden 2017).

Weduwen, Arthur der, 'Booksellers, Newspaper Advertisements and a National Market for Print in the Seventeenth-Century Dutch Republic', in Shanti Graheli (ed.), Buying and Selling. The Business of Books in Early Modern Europe (Leiden, forthcoming).

Welke, Martin, 'Johann Carolus und der Beginn der periodischen Tagespresse. Versuch, einen Irrweg der Forschung zu korrigieren', in Martin Welke and Jürgen Wilke (eds.), 4oo Jahre Zeitung. Die Entwicklung der Tagespresse im internationalen Kontext (Bremen 2008), 9-116. 